\title{
DAMPAK PANDEMI COVID-19 TERHADAP MASYARAKAT NELAYAN SEKITAR PPN KARANGANTU
}

\section{Impact of Covid-19 Pandemic on Fishermen Community Around Karangantu Fishing Port}

Oleh:

Asep Hamzah ${ }^{* 1}$, Hery Sutrawan Nurdin ${ }^{1}$

'Program Studi Ilmu Perikanan, Universitas Sultan Ageng

Tirtayasa, Jl. Raya Jakarta KM 04 Pakupatan Kota Serang,

Provinsi Banten

*Korespondensi penulis: asep.hamzah@untirta.ac.id

\begin{abstract}
ABSTRAK
Diterapkannya social/physical distancing, PSBB, lockdown menyebabkan terbatasnya pergerakan manusia dan barang, sehingga berdampak pada terputusnya rantai pemasaran/distribusi, salah satunya perikanan. Dampak yang harus ditanggung oleh keluarga nelayan dan pelaku perikanan rakyat akibat penyebaran virus, antara lain potensi lumpuhnya kehidupan ekonomi dalam bentuk menurunnya pendapatan karena terputusnya rantai pemasaran ikan dari nelayan sebagai produsen kepada masyarakat luas sebagai konsumen. Penelitian ini bertujuan untuk mengetahui dampak pandemi covid-19 terhadap masyarakat nelayan di sekitar PPN Karangantu. Metode yang digunakan dalam penelitian ini adalah studi kasus terhadap nelayan yang terdampak pandemi Covid-19 di PPN Karangantu. Data penelitian diperoleh dengan cara melakukan wawancara dan pengamatan langsung secara purposive sampling. Kemudian hasil wawancara dan pengamatan dianalisis secara statistik deskriptif. Dampaknya terhadap kegiatan perikanan pada masyarakat nelayan di sekitar PPN Karangantu antara lain: (1) harga jual ikan hasil tangkapan rendah; (2) distribusi ikan hasil tangkapan terhambat; (3) perubahan frekuensi operasi penangkapan ikan; (4) pengurangan jumlah anak buah kapal.
\end{abstract}

Kata kunci: Covid-19, PPN Karangantu, pelabuhan perikanan

\begin{abstract}
Implementation of social/physical distancing, PSBB, and lockdown causes limited movement of people and goods, resulting in a break in the marketing/distribution chain, one of which is fisheries. The impact that must be borne by fishermen's families and community fishermen actors due to the spread of the virus, among others, is the potential for economic life to be paralyzed in the form of decreased income due to the disconnection of the fish marketing chain from fishermen as producers to the wider community as consumers. This study aims to determine the impact of the Covid-19 pandemic on fishing communities around PPN Karangantu. The method used in this research is a case study of fishermen affected by the Covid-19 pandemic at PPN Karangantu. The research data were obtained by conducting interviews and direct observation by means of purposive sampling. Then the results of interviews and observations were analyzed using descriptive statistics. The impact on fishery activities on fishing communities around PPN Karangantu includes: (1) low selling price of fish caught; (2) distribution of catched fish is obstructed; (3) changes in fishing operation frequency; (4) reducing number of crew members.
\end{abstract}

Key words: Covid-19, fishing port, PPN Karangantu 


\section{PENDAHULUAN}

Coronaviruses Deaseas 2019 atau lebih dikenal dengan nama Covid-19 merupakan virus yang pertama kali ditemukan di Wuhan, China pada Desember 2019, dan menyebar ke Indonesia pada bulan Maret 2019. Coronaviruses (CoV) merupakan bagian dari keluarga virus yang menyebabkan penyakit mulai dari flu hingga penyakit yang lebih berat seperti Middle East Respiratory Syndrome (MERS-CoV) and Severe Acute Respiratory Syndrome (SARS-CoV). Penyakit Covid-19, adalah jenis baru yang ditemukan pada tahun 2019 dan belum pernah diidentifikasi menyerang manusia sebelumnya (World Health Organization, 2019).

Coronaviruses ini bisa menyebar secara cepat dari manusia ke manusia dari droplet ketika bersin dan batuk. Karena penularan virus corona yang sangat cepat inilah Organisasi Kesehatan Dunia (WHO) menetapkan virus corona sebagai pandemi pada 11 Maret 2020. Status pandemi atau epidemi global menandakan bahwa penyebaran COVID-19 berlangsung sangat cepat hingga hampir tak ada negara di dunia yang dapat memastikan diri terhindar dari virus corona (Widiyani, 2020).

Mengantisipasi dan mengurangi jumlah penderita virus corona di Indonesia sudah dilakukan di seluruh daerah. Di antaranya dengan memberikan kebijakan membatasi aktivitas keluar rumah, kegiatan sekolah dirumahkan, bekerja dari rumah (work from home), bahkan kegiatan beribadah pun dirumahkan.

Pola penyebaran corona virus seperti ini, menyebabkan diterapkannya social/physical distancing, Pembatasan Sosial Berskala Besar (PSBB) hingga lockdown untuk memutus mata rantai penyebaran Covid-19 (Zaharah et al. 2020). Kebijakan tersebut dapat membantu mencegah penyebaran virus corona ke suatu wilayah, sehingga masyarakat yang berada di suatu wilayah tersebut diharapkan dapat terhindar dari wabah yang cepat menyebar tersebut. Kebijakan ini hanya dapat dilakukan oleh pemerintah, dengan terlebih dahulu melakukan pemeriksaan secara ketat sebelumnya ke beberapa wilayah dan mempertimbangkan konsekuensinya secara matang, baik dari segi ekonomi maupun sosial. Kebijakan ini merupakan bagian dari peraturan perundang-undangan yang tertuang dalam Undang-Undang Nomor 6 tahun 2018 tentang Kekarantinaan Kesehatan yang membahas Kekarantinaan Kesehatan di Pintu Masuk dan di wilayah dilakukan melalui kegiatan pengamatan penyakit dan Faktor Risiko Kesehatan Masyarakat terhadap alat angkut, orang, barang, dan/atau lingkungan, serta respons terhadap Kedaruratan Kesehatan Masyarakat dalam bentuk tindakan Kekarantinaan Kesehatan (Yunus et al. 2020).

Diterapkannya social/physical distancing, PSBB, lockdown menyebabkan terbatasnya pergerakan manusia dan barang, sehingga berdampak pada terputusnya rantai pemasaran/distribusi, salah satunya perikanan. Dampak yang harus ditanggung oleh keluarga nelayan dan pelaku perikanan rakyat akibat penyebaran virus, antara lain potensi lumpuhnya kehidupan ekonomi dalam bentuk menurunnya pendapatan karena terputusnya rantai pemasaran ikan dari nelayan sebagai produsen kepada masyarakat luas sebagai konsumen.

Nelayan merupakan suatu kelompok masyarakat yang kehidupannya bergantung pada hasil laut. Akibat dapat menyebabkan tingkat perekonomian seorang nelayan tidak menentu bahkan terkadang nihil. Sehingga, perekonomian nelayan mengalami ketidakstabilan. Mengingat kebutuhan sehari-hari seiring berjalannya waktu barang-barang kebutuhan rumah tangga semakin mahal. Hal tersebut akan membuat nelayan terdorong untuk melakukan sebuah tindakan yang bertujuan untuk memperbaiki perekonomian keluarganya.

Kondisi pandemi ini, telah menjadi kekhawatiran semua pihak, pembahasan mengenai ketahanan ekonomi baik secara makro maupun mikro menjadi topik yang sering dibicarakan akhirakhir ini. Hal ini tidak lain karena tidak ada kepastian kapan pandemi Covid-19 akan berakhir. Penelitian terdahulu mengenai ketahanan ekonomi, lebih terfokus pada perubahan iklim atau saat menghadapi iklim ekstrim seperti banjir, kekeringan dan hama yang menjadi penyebab gagal panen. 
PPN Karangantu merupakan salah satu pelabuhan yang menjual ikan hasil tangkapannya ke Jakarta (Gumilang et al. 2017). Maka, ketika pemerintah DKI Jakarta memberlakukan PSBB, nelayan dari PPN Karangantu tidak bisa melakukan distribusi ikan hasil tangkapannya. Hal ini tentu saja berdampak terhadap nelayan di PPN Karangantu. Penelitian ini bertujuan untuk melihat dampak apa saja yang dialami oleh nelayan PPN Karangantu selama Pandemi Covid-19.

Sebelum adanya Pandemi Covid-19, ikan hasil tangkapan dari PPN Karangantu, selain untuk konsumsi masyarakat lokal, juga dikirim untuk dijual ke pasar ikan Muara Baru Jakarta. Menurut Gumilang et al. (2015) selain mengirimkan ikan hasil tangkapan ke pasar ikan Muara Baru Jakarta, PPN Karangantu juga menerima ikan hasil tangkapan dari Jakarta. Hamzah et al. (2015) juga menyatakan bahwa ikan hasil tangkapan dari luar PPN Karangantu dikirim ke PPN Karangantu untuk memenuhi kebutuhan pasar dan bahan baku ikan olahan. Keluar masuknya ikan hasil tangkapan melalui jalur darat ini tidak dicatat di PPN Karangantu, namun, berdasarkan pengamatan awal, diperkirakan sekitar 2-3 ton per hari ikan hasil tangkapan di PPN Karangantu dikirim untuk dijual ke Jakarta. Ikan hasil tangkapan yang dikirim antara lain seperti tenggiri, tongkol, udang, cumi, dan teri. Untuk rajungan, dikirim langsung ke Jakarta dengan tujuan ekspor. Jumlah rajungan yang dikirim per hari bisa mencapai \pm 1 ton per hari. Selain dikirim ke pasar ikan Muara Baru Jakarta, ikan hasil tangkapan dari PPN Karangantu juga didistribusikan ke pasar lokal, pedagang eceran yang menjual ikan secara keliling, dan pengolah ikan di sekitar PPN Karangantu.

PPN Karangantu merupakan salah satu tulang punggung penghasil produk perikanan tangkap untuk mensuplai kebutuhan protein ikan di Provinsi Banten. Kebutuhan protein ikan di Provinsi Banten setidaknya sebesar 66,46 gram per hari yang merupakan tingkat konsumsi ikan masyarakat (Susanto et al. 2020). Sehingga, adanya pandemi ini, diduga mempengaruhi masyarakat nelayan di PPN Karangantu. Tingkat konsumsi ikan ini masih relatif rendah dibandingkan dengan produksi ikan hasil tangkapan yang dihasilkan. Rata-rata produksi perikanan di Provinsi Banten mencapai \pm 53.000 ton per tahun (DKP Provinsi Banten 2018). Maka, jika dihubungkan dengan tingkat konsumsi ikan yang baru mencapai 66,46 gram per hari maka ada banyak kelebihan ikan di sisi produsen. Kelebihan produksi ini jika tidak didistribusikan ke berbagai wilayah, baik itu ke Jakarta atau kota/kabupaten lain di dalam Provinsi Banten, maka akan menyebabkan terjadinya penurunan harga ikan dan merugikan nelayan. Sehingga pandemi Covid-19 ini perlu dikaji agar dapat diketahui sampai sejauh mana dampak yang dialami oleh masyarakat nelayan.

\section{METODE PENELITIAN}

Metode yang digunakan adalah studi kasus terhadap dampak pandemi Covid-19 terhadap masyarakat nelayan di sekitar PPN Karangantu. Pengumpulan data dilakukan melalui pengamatan langsung di lapangan (observasi), wawancara mendalam terhadap tokoh-tokoh kunci dalam penelitian. Penentuan responden dilakukan secara purposive sampling. Wawancara ditujukan kepada pihak yang terdampak akibat adanya pandemi Covid-19 di PPN Karangantu, antara lain kepada pemilik kapal (juragan), antara lain:

Tabel 1 Jumlah Responden

\begin{tabular}{lc}
\hline \multicolumn{1}{c}{ Pemilik Kapal } & Jumlah \\
\hline Gillnet & 12 \\
Boat Lift Net & 8 \\
Trammel Net & 8 \\
Dredge & 3 \\
\hline Total & 31 \\
\hline
\end{tabular}


Analisis data yang digunakan adalah metode deskriptif kualitatif untuk mengidentifikasi dampak pandemi Covid-19 terhadap aktivitas masyarakat nelayan. Aspek yang diteliti antara lain aktivitas yang berhubungan dengan kegiatan perikanan di masyarakat nelayan sebelum dan sesudah terjadinya pandemi Covid-19.

\section{HASIL DAN PEMBAHASAN}

Pelabuhan Perikanan Nusantara (PPN) Karangantu, merupakan pelabuhan perikanan dengan tipe terbesar (Tipe B) di Provinsi Banten. Hal ini menjadi daya tarik bagi nelayan, untuk menjual ikan hasil tangkapannya di PPN Karangantu. Hamzah et al. (2015) menyatakan bahwa harga ikan di PPN Karangantu relatif lebih tinggi dibanding dengan harga ikan di pelabuhan perikanan sekitarnya. Ikan hasil tangkapan yang didaratkan selama 5 tahun terakhir memiliki kecenderungan meningkat setiap tahunnya dengan rata-rata produksi sebesar 2,262 ton/tahun.

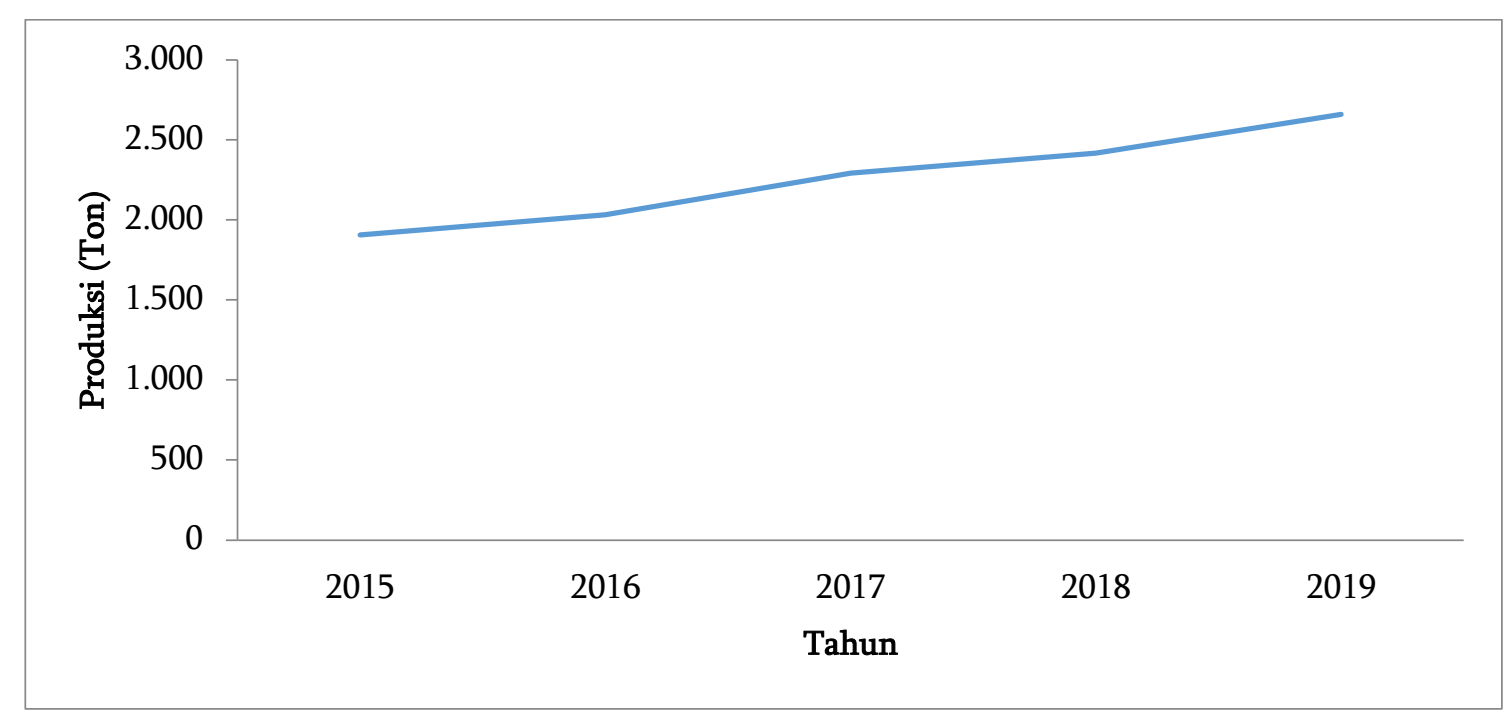

Gambar 1 Grafik Produksi Ikan Hasil Tangkapan di PPN Karangantu 2015-2019

Selain dipasarkan di dalam kawasan PPN Karangantu, ikan hasil tangkapan yang didaratkan juga dipasarkan ke luar kawasan PPN Karangantu baik itu ke wilayah yang ada di Provinsi Banten juga keluar Provinsi Banten. Gumilang et al. (2017) menyatakan bahwa ikan hasil tangkapan di PPN Karangantu dipasarkan juga ke DKI Jakarta. Hal ini dilakukan oleh nelayan dan pedagang untuk memperoleh harga ikan yang lebih tinggi.

Ikan hasil tangkapan dominan di PPN Karangantu pada tahun 2019 (Tabel 2 dan Gambar 2) antara lain secara berturut-turut adalah pepetek, cumi-cumi, teri, kembung, kuniran, tembang, kurisi, tenggiri, lemuru dan layang. Ikan pepetek, oleh sebagian besar nelayan dijual kepada pengolah ikan asin. Daya serap pengolah ikan untuk ikan pepetek hanya berkisar 100-115 kg per hari. Untuk cumicumi, teri, kembung, kuniran, tembang, kurisi, tenggiri, lemuru dan layang jumlah ikan hasil tangkapan yang dikirim ke pasar ikan Muara Baru Jakarta, tidak menentu, tergantung permintaan 'pasar' di pasar ikan tersebut. Jika harga sedang tinggi di Jakarta, maka sebanyak $60 \%$ hasil tangkapan akan dikirim ke Jakarta. Pengiriman ikan hasil tangkapan dilakukan menggunakan blong dan box diberi es curah kemudian diangkut menggunakan mobil bak Colt T120ss. Khusus ikan teri, selain dijual langsung ke pasar ikan Muara Baru Jakarta, juga dikirim ke perusahaan ekspor.

Ikan-ikan tersebut, selain dikirim ke pasar ikan Muara Baru Jakarta, Juga dikirim ke pasar tradisional sekitar, seperti pasar Karangantu, pasar Rau, dan ada juga dikirim langsung ke konsumen. Untuk distribusi ikan hasil tangkapan ke pasar tradisional menggunakan mobil bak colt T120ss menggunakan blong dan box yang diberi es curah. 
Tabel 2 Jumlah Produksi Ikan Hasil Tangkapan Dominan di PPN Karangantu, 2019

\begin{tabular}{l|r}
\hline Jenis Ikan Hasil Tangkapan & Produksi Tahun 2019 (ton) \\
\hline Pepetek & 284.4 \\
Cumi-cumi & 281.4 \\
Teri & 239.6 \\
Kembung & 219.8 \\
Kuniran & 217.3 \\
Tembang & 207.0 \\
Kurisi & 123.8 \\
Tenggiri & 26.8 \\
Lemuru & 22.4 \\
Layang & 21.0 \\
\hline
\end{tabular}

Sumber : Statistik Tahunan PPN Karangantu, 2019

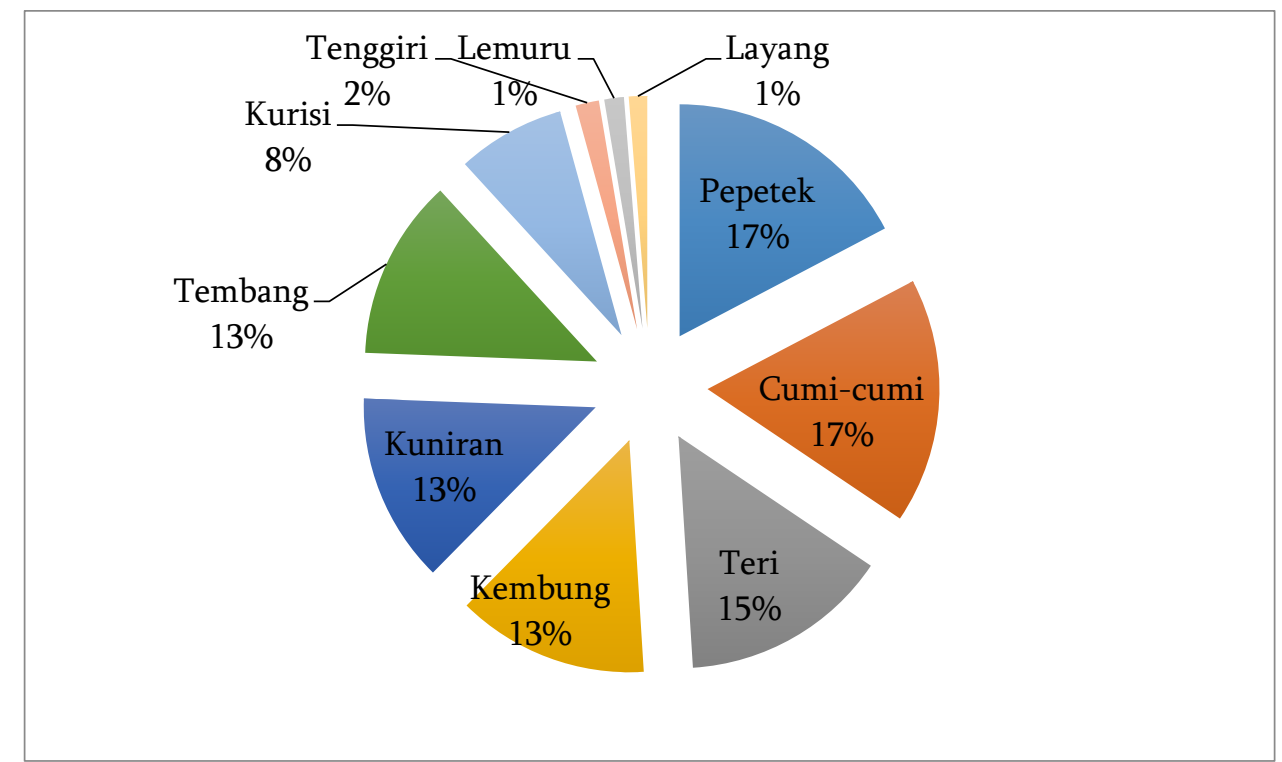

Gambar 2 Persentase Produksi Ikan Hasil Tangkapan di PPN Karangantu 2019

Ikan hasil tangkapan yang didistribusikan langsung ke konsumen menggunakan motor yang di samping kanan kirinya dipasang blong (Gambar 3). Rata-rata jumlah ikan yang dibeli berkisar antara 10-15 kg. ikan yang dibeli jarang sekali lebih dari satu jenis ikan. Ikan yang dijual ke konsumen hanya jenis ikan tertentu saja yang populer dikonsumsi oleh masyarakat. 


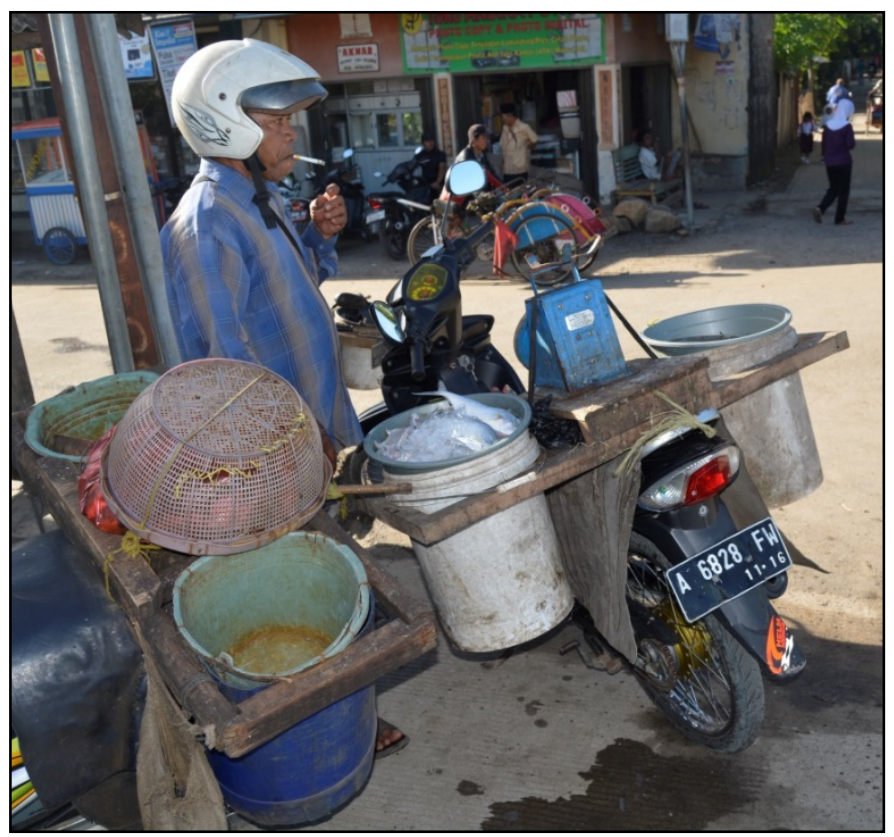

Gambar 3 Alat Transportasi Ikan Hasil Tangkapan dari PPN Karangantu Langsung ke Konsumen

Kegiatan distribusi ikan hasil tangkapan ini, terhambat selama tiga bulan terakhir selama pemberlakuan PSBB di DKI Jakarta. Ikan hasil tangkapan akhirnya menumpuk di PPN Karangantu dan mengalami dampak bagi nelayan dalam berbagai aktivitasnya. Dampak yang paling terasa selama pandemi adalah terhambatnya proses distribusi ikan hasil tangkapan (96,8\%). Mengingat sebagian besar nelayan $(>50 \%)$ menjual ikan hasil tangkapannya ke Jakarta. Selain itu, dampak lain yang dirasakan oleh nelayan adalah harga ikan menurun (88.6\%),pengurangan jumlah ABK $(80,8 \%)$ dan frekuensi melaut berubah (76,8\%), lebih lengkap disajikan pada Gambar 4.

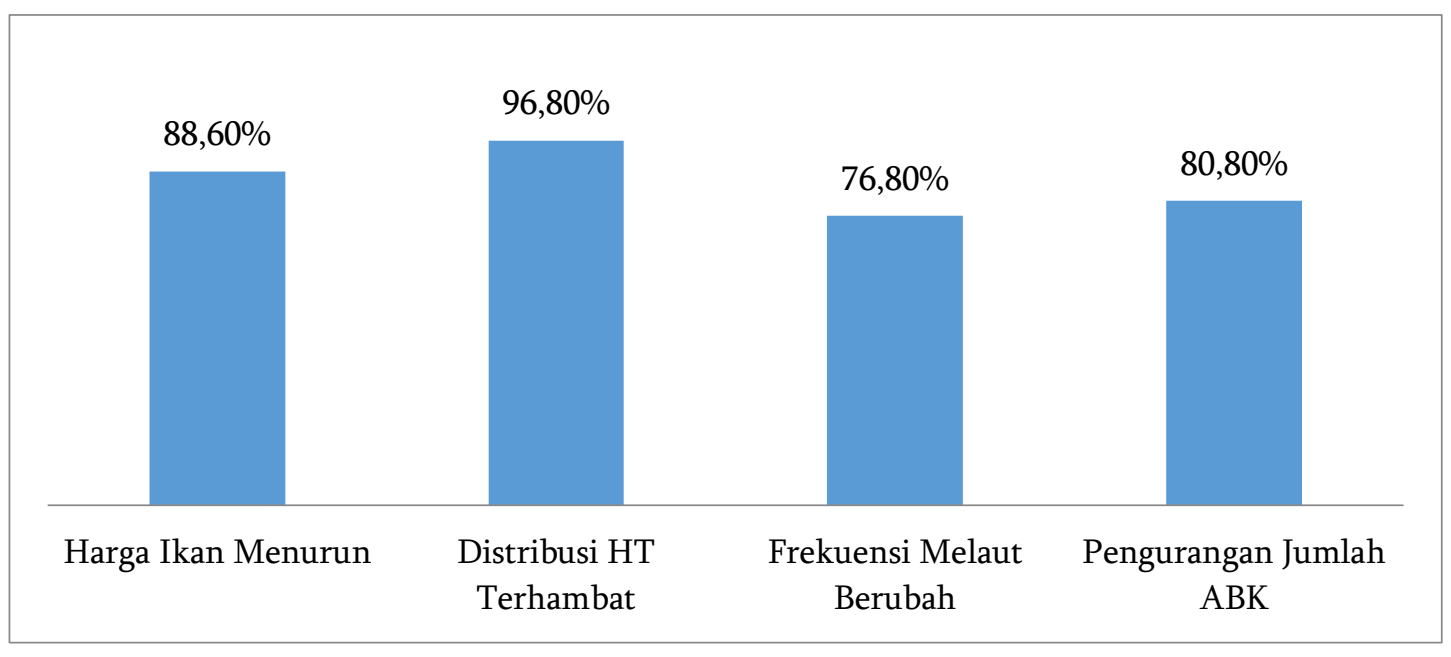

Gambar 4 Persentase Dampak yang Dialami Nelayan Selama Pandemi

Distribusi Ikan Hasil Tangkapan Terhambat

Gumilang et al. (2017) mengungkapkan bahwa pemasaran ikan hasil tangkapan yang didaratkan di PPN Karangantu juga dipasarkan ke pasar ikan yang ada di PPS Muara Baru dan PPI Muara Angke. Akan tetapi, selama pandemi Covid-19 terutama saat Pemerintah Provinsi DKI Jakarta memberlakukan Pembatasan Sosial Berskala Besar (PSBB), nelayan mengalami kesulitan untuk menjual ikan hasil tangkapannya ke Jakarta. Bahkan pada periode awal PSBB, tidak ada pengiriman ikan sama sekali. Akibatnya ikan menumpuk dan disimpan di freezer. Sebenarnya nelayan dari luar 
tetap bisa masuk dan menjual ikan hasil tangkapannya jika ditransportasikan melalui laut (Irawan 2020). Berdasarkan pengamatan, nelayan PPN Karangantu mengirimkan ikan hasil tangkapannya menggunakan jalur darat. Suherman et al. (2020) menyatakan bahwa distribusi ikan hasil tangkapan melalui jalur darat ke Jakarta karena suplai ikan hasil tangkapan di PPN Karangantu berlebih.

Kelompok nelayan yang terdampak antara lain nelayan bagan perahu, dan nelayan rajungan. Nelayan rajungan sebagaimana dijelaskan di atas, prioritas pasarnya memang untuk pasar Jakarta dan ekspor (Putri et al. 2013). Sehingga adanya PSBB di DKI Jakarta menyebabkan kegiatan pemasaran menjadi terhambat. Sedangkan untuk nelayan bagan perahu, hanya ikan yang memiliki kualitas prima saja yang akhirnya tidak bisa didistribusikan ke Jakarta. Selain itu, masih terdapatnya pedagang eceran yang menjajakan ikan hasil tangkapan nelayan ke beberapa wilayah di Kota dan Kabupaten Serang menyebabkan kebijakan PSBB DKI Jakarta tidak terlalu berdampak. Hal yang sama dialami juga oleh nelayan garok. Hasil tangkapan nelayan garok berupa kerang, masih bisa didistribusikan dan dipasarkan karena memang area konsumennya masih di sekitar Provinsi Banten.

\section{Harga Jual Ikan Hasil Tangkapan Rendah}

Salah satu alasan mengapa nelayan di PPN Karangantu mendistribusikan ikan hasil tangkapannya ke pasar DKI Jakarta adalah untuk memperoleh harga jual yang relatif tinggi sehingga mampu memperoleh keuntungan yang relatif lebih besar. Perbedaan harga pasar di PPN Karangantu dan DKI Jakarta bisa mencapai 50\%.

Komoditas yang memiliki nilai tinggi dan menjadi prioritas untuk kegiatan ekspor dan pemasaran di DKI Jakarta salah satunya adalah rajungan. Nelayan rajungan yang ber fishing base di PPN Karangantu, lebih memilih menjual rajungan ke pengumpul untuk kemudian dikirim ke Jakarta. Harga rajungan di pasar DKI Jakarta dibagi menjadi dua kategori, yaitu produk rajungan hidup dan rajungan mati. Untuk rajungan hidup, maka konsumen atau pembeli di Jakarta akan membeli dikisaran harga Rp75.000-Rp85.000 per kg. sedangkan untuk rajungan dalam kondisi mati dihargai Rp40.000- Rp50.000 per kg.

Saat terjadi pandemi Covid-19, aktivitas distribusi rajungan dari PPN Karangantu ke Jakarta menjadi terhambat bahkan tidak bisa dilakukan. Hal ini berakibat pada harga jual rajungan menjadi rendah. Rajungan hidup bahkan dijual dengan harga Rp40.000 per $\mathrm{kg}$ dan rajungan mati dijual dengan harga Rp20.000 per kg.

Penurunan harga jual juga terjadi pada nelayan bagan congkel (bagan perahu) dan nelayan garok. Pada nelayan bagan congkel, penurunan harga jual ikan hasil tangkapan tidak seperti nelayan rajungan yang mencapai 50\%. Harga jual ikan hasil tangkapan nelayan bagan congkel berkisar antara 10\%-12\%. Sebagian besar ikan hasil tangkapannya merupakan komoditas yang biasa dijual oleh pedagang pengecer ke perkampungan warga. Hamzah et al. (2015) menyatakan bahwa proporsi ikan hasil tangkapan di PPN Karangantu yang dijual segar hanya mencapai 64\% (1,5 ton) dari rata-rata produksi 2,3 ton/tahun. Sisanya dimanfaatkan oleh warga sekitar untuk dijadikan ikan asin. Keberadaan industri pengolahan dan pedagang eceran membuat penurunan harga pada harga jual ikan hasil tangkapan tidak begitu besar. Pandemi juga berdampak pada daya beli masyarakat yang menurun (Kurniawansyah et al. 2020) sehingga penawaran terhadap ikan hasil tangkapan menurun yang berakibat pada menurunnya harga jual.

Kelompok nelayan yang mengalami dampak terkecil dari adanya pandemi adalah nelayan garok dengan hasil tangkapan utamanya adalah kerang-kerangan. Mayoritas ikan hasil tangkapannya adalah hasil budidaya nelayan setempat berupa kerang hijau. Berdasarkan hasil wawancara, permintaan kerang hijau untuk didistribusikan ke beberapa wilayah di Kota Serang, Kota Cilegon masih seperti biasa. Selain itu, kerjasama dengan pihak dompet dhuafa dalam hal pengolahan daging kerang hijau turut membuat permintaan akan kerang hijau tidak mengalami penurunan. 


\section{Perubahan Frekuensi Operasi Penangkapan Ikan}

Pemberlakuan PSSB di DKI Jakarta yang kemudian menyebabkan harga ikan turun dan kesulitan untuk melakukan distribusi, berdampak juga pada perubahan frekuensi melaut. Nelayan bagan perahu dan nelayan rajungan, sebelum pandemi Covid-19 melakukan operasi penangkapan ikan sebanyak enam kali dalam seminggu. Hari libur hanya pada hanya Jumat yang dikhususkan untuk beribadah. Adanya pandemi Covid-19 menyebabkan frekuensi melaut menjadi berkurang menjadi tiga kali dalam seminggu. Penyebabnya yaitu nelayan tidak memiliki modal yang cukup untuk penyediaan perbekalan melaut. Hal ini dikarenakan pendapatan nelayan menjadi berkurang akibat dari turunnya harga jual dan distribusi yang terhambat karena adanya PSBB. Nelayan terpaksa mengurangi frekuensi operasi penangkapan ikan karena stok ikan hasil tangkapan masih banyak yang belum terjual. Beberapa nelayan rajungan bahkan lebih memilih untuk tidak melaut terlebih dahulu sampai harga rajungan kembali normal.

\section{Pengurangan Jumlah Anak Buah Kapal (ABK)}

Pengurangan jumlah ABK yang ikut melaut dialami oleh nelayan bagan perahu. Nelayan rajungan dan nelayan garok tidak mengalami hal ini dikarenakan jumlah orang untuk satu kali kegiatan penangkapan paling banyak hanya empat orang dan sebagian besar merupakan kerabat atau anggota keluarga.

Jika semula nelayan bagan perahu membawa sekitar 8-10 orang untuk sekali kegiatan penangkapan ikan, maka selama pandemi Covid-19 hanya membawa enam orang saja untuk sekali kegiatan penangkapan ikan. Pengurangan ini dilakukan karena terhambatnya proses pemasaran ikan hasil tangkapan sebagaimana diuraikan sebelumnya. Untuk memperoleh keuntungan yang sedikit lebih besar, maka salah satu solusi adalah mengurangi jumlah ABK yang ikut serta dalam kegiatan penangkapan.

\section{KESIMPULAN DAN SARAN}

Berdasarkan uraian sebelumnya, maka dapat disimpulkan bahwa dampak yang dialami oleh masyarakat nelayan di sekitar PPN Karangantu selama pandemi Covid-19 antara lain:

1. Harga jual ikan hasil tangkapan rendah;

2. Distribusi ikan hasil tangkapan terhambat;

3. Perubahan frekuensi operasi penangkapan ikan;

4. Pengurangan jumlah anak buah kapal.

\section{DAFTAR PUSTAKA}

Gumilang AP, Iin S, Sugeng HW. (2017). Pola Distribusi dan Teknologi Pengelolaan Hasil Tangkapan Pelabuhan Perikanan di Wilayah Pantura Jawa. Jurnal Teknologi Perikanan dan Kelautan. Vol 5 (1) Mei 2014: 65-74.

Hamzah A, Anwar BP, Ernani L. 2015. Potensi Ikan Unggulan Sebagai Bahan Baku Industri Pengolahan Di PPN Karangantu. Marine Fisheries: Journal of Marine Fisheries Technology and Management. 6(1). 45-58.

Irawan R. 2020. Kepala Pelabuhan Perikanan Samudera Nizam Zachman Jakarta. [Komunikasi Pribadi].

Kurniawansyah, H., Salahuddin, A.M., Nurhidayati, S., 2O20, Konsep Kebijakan Strategis dalam Menangani Eksternalitas Ekonomi dari Covid-19 Pada Masyarakat Rentan di Indonesia, Indonesian Journal of Social Sciences and Humanities, 1(2): 130-139. 
Putri RLC, Fitri ADP dan Yulianto T. 2013. Analisis Perbedaan Jenis Umpan dan Lama Waktu Perendaman Pada Alat Tangkap Bubu Terhadap Hasil Tangkapan Rajungan di Perairan Suradadi Tegal. Journal of Fisheries Resources Utilization Management and Technology (2): 51-60.

Suherman A, Herry B, Faik K, Abdul KM. 2020. Kinerja Pelabuhan Perikanan Nusantara (PPN) Karangantu, Banten, Indonesia. Depik Jurnal Ilmu-Ilmu Perairan, Pesisir dan Perikanan. 9(2): 344-355.

Susanto A, Hamzah A, Irnawati R, Nurdin HS, Supadminingsih FN. 2020. Peran Sektor Perikanan Tangkap dalam Mendukung Ketahanan Pangan Perikanan di Provinsi Banten. Leuit Journal of Local Food Security. Vol 1(1) 2020: 9-17.

Wahyono A. 2001. Pemberdayaan Masyarakat Nelayan. Yogyakarta (ID): Meida Pressindo

[WHO] World Health Organization. (2019). Coronavirus. Retrieved from World Health Organization: https://www.who.int/healthtopics/coronavirus.

Widiyani, R. (2020). Latar Belakang Virus Corona, Perkembangan hingga Isu Terkini. Retrieved from detikNews:https://news.detik.com/berita/d4943950/latar-belakang-viruscoronaperkembangan-hingga-isu-terkini.

Yunus NR, Annisa R. 2020. Kebijakan Pemberlakuan Lock Down Sebagai Antisipasi Penyebaran Corona Virus Covid-19. SALAM Jurnal Sosial dan Budaya Syar'i. 7(3).

Zaharah, Galia IK. 2020. Impact of Corona Virus Outbreak Towards Teaching and Learning Activities in Indonesia. SALAM Jurnal Sosial dan Budaya Syar'i. 7(3). 